Volume 2 Nomor 2, Desember 2019

E-ISSN : 2655-7347

\title{
KEBIJAKAN HUKUM PIDANA PENGGUNAAN NARKOTIKA GOLONGAN 1 (SATU) JENIS “GANJA” UNTUK KESEHATAN
}

\author{
Karen Abigael Pangkey \\ (Mahasiswa Program S1 Fakultas Hukum Universitas Tarumanagara) \\ (E-mail: karenabigaelpangkey@gmail.com)
}

\section{R. RAHADITYA, S.H., M.H}

(Corresponding Author)

(Dosen Fakultas Hukum Universitas Tarumanagara. Meraih Sarjana Hukum pada Fakultas Hukum Universitas Tarumanagara, Magister Hukum pada Fakultas Hukum Universitas Tarumanagara.

(E-mail: rahaditya@mku.untar.ac.id)

\begin{abstract}
Health is a healthy condition, physically, mentally, spiritually, and socially that enables everyone to live productively socially and economically. In maintaining his health, in order to survive, it is not uncommon for a person to use narcotics as a treatment he must live. Like the incident in the $111 /$ Pid.Sus / 2017 / Pn.Sag case. Where Yeni was given Marijuana by her husband as a treatment, previously Yeni had tried various treatments in the medical and traditional fields. When there was a urine test in Fidelis's office, Fidelis asked the National Narcotics Agency about how to treat cannabis treatment, a few days after that, Fidelis was immediately arrested at his home and detained. While in prison, Yeni passed away. How is the application of the principle of justice in imposing crimes against Fidelis? Fidelis was sentenced to 8 (eight) months in prison and a fine of Rp1,000,000,000 (one billion rupiah) and was replaced with a prison of 1 (one) month if he could not pay the fine. In this study, the author uses normative legal methods and uses interview data as supporting data. The results of the study that the authors conclude that Fidelis should not be convicted because Fidelis is an act of force or in an emergency, here there is freedom of judges in deciding cases, and there is a difference between applicable law (das sollen) with existing practice (das sein ).

Keywords: Marijuana, Narcotics, Criminal Code, BNN, and Health
\end{abstract}

\section{PENDAHULUAN}

\section{A. Latar Belakang}

Kesehatan adalah keadaan sehat, baik secara fisik, mental, spritual, maupun sosial yang memungkinkan setiap orang untuk hidup produktif secara sosial dan ekonomis. ${ }^{1)}$ Maka karena itu secara tidak langsung, kesehatan adalah modal utama yang sangat diperlukan oleh manusia agar bisa beraktivitas secara produktif untuk diri sendiri dan sekitarnya. Kadang

1) Indonesia, Undang-undang Nomor 36 Tahun 2009 tentang Kesehatan (Lembaran Negara Repubik Indonesia Tahun 2009 Nomor 114, Tambahan Lembaran Negara Republik Indonesia Nomor 5063), Pasal 1. 
Volume 2 Nomor 2, Desember 2019

E-ISSN : 2655-7347

pengobatan yang masih kurang di Indonesia menjadi salah satu alasan kesehatan tidak dapat diperoleh dengan maksimal.

Dalam beberapa tahun belakangan ini, terdapat lebih dari 1 (satu) kasus yang diketahui beberapa orang memakai narkotika golongan 1 (satu) jenis Ganja (selanjutnya disebut ganja) dalam mengobati penyakit yang dialaminya dengan alasan kekurangan biaya ataupun alasan kurangnya pengobatan yang memadai yang ada di Indonesia. Secara etimologis, istilah "ganja" diambil dari bahasa sansekerta yang sama dengan arti di Indonesia. Sedangkan secara ilmiah ganja memiliki nama "Cannabis sativa" yang diberikan oleh Carrolus Linnaeus pada tahun 1753.2) Pada kenyataannya, sejarah mengatakan sendiri kalau "cannabis" atau "ganja” adalah salah satu kata dengan akar bahasa yang tertua di dunia. ${ }^{3)}$

Di dalam Peraturan Nomor 35 Tahun 2009 tentang Narkotika Pasal 7 menyebutkan Narotika hanya dapat digunakan untuk kepentingan pelayanan kesehatan dan atau pengembangan ilmu pengetahuan dan teknologi. Namun ganja tidak masuk di dalam golongan Narkotika yang bisa digunakan untuk kesehatan. Hal ini terjadi karena ganja masuk ke golongan I narkotika. ${ }^{4)}$ dan narkotika golongan I dilarang digunakan untuk kepentingan pelayanan kesehatan 5)

Ini membuat ganja menjadi tanaman yang kontroversial karena sejarahnya yang lekat dengan budaya di Indonesia. Di Aceh, tanaman ini berfungsi sebagai penyedap masakan untuk berbagai jenis masakan, seperti gulai kambing, dodol Aceh, mie Aceh, kopi Aceh dan sebagainya untuk

\footnotetext{
2) Aristedes Julian, Alegori 420, (Yogyakarta: Vice Versa Books, 2018), hal. 1

3) Tim Lgn, Hikayat Pohon Ganja 12000 Tahun Menyuburkan Peradaban Manusia, Edisi ke 2(Jakarta: Gramedia Pustaka Utama, 2018), hal. 4

4) Peraturan Menteri Kesehatan Republik Indonsia Nomor 50 Tahun 2018 tentang Perubahan Penggolongan Narkotika

5) Indonesia, Undang-undang Nomor 35 Tahun 2009 tentang Narkotika (Lembaran Negara Repubik Indonesia Tahun 2009 Nomor 143, Tambahan Lembaran Negara Republik Indonesia Nomor 5062), Pasal 8.
} 
Volume 2 Nomor 2, Desember 2019

E-ISSN : 2655-7347

menambah cita rasa makanan. Sejarah mengatakan, tanaman ganja masuk ke daerah Aceh sejak abad ke-19, berasal dari India. Ketika itu, Belanda membuka perkebunan kopi di Dataran Tinggi Gayo dan menggunakannya sebagai obat alami untuk menghindari serangan hama pohon kopi atau ulat pada tanaman tembakau. Bertahun-tahun lamanya dan tumbuh menyebar hampir di seluruh daera Aceh, ganja mulai dikonsumsi, terutama dijadikan 'rokok enak, yang lambat laun menjadi tradisi di Aceh hingga daerah lain di Sumatera sebagai tambahan rempah dalam resep masakan. ${ }^{6)}$

Di Peradaban Romawi Tanaman ganja merupakan tanaman yang sangat strategiis dengan berbagai kegunaan. Marijuana dimanfaatkan sebagai analgesic (penghilang rasa sakit) dalam melakukan peperangan, bahan untuk tali-temali, tekstilm minyak untuk penerangan, memasak, dan lain-lainnya. Fungsi yang banyak ini melahirkan istilah "cannapaceus" atau "canape" yang bermakna 'segala sesuatu yang dibuat dari cannabis. ${ }^{7\}}$

Jika melihat di negara lain, beberapa negara sudah melegalkan ganja guna untuk dipakai medis dan untuk menurunkan tindak kriminal. Pada bulan Juni 2012, Presiden Uruguay yaitu Jose Mujica, mengumumkan rencana untuk melegalkan penjualan ganja yang dikontrol sendiri oleh pemerintah. Rencana ini nantinya dipercaya akan menumbuhkan tanaman untuk penggunaan non-kemersial dan lisensi hibah untuk petani profesional untuk produksi skala besar. Rencana ini juga akan memakai sistem pengguna, pajak, dan kontrol kualitas, semua dikoordinasikan melalui lembaga yang dibentuk oleh pemerintah yang memantau tembakau, alkohol, dan obat-obatan. Pelegalan itu terealisasi setelah disahkannya RUU tentang pelegalan ganja

6) Hanri Aldino, "Persepsi Mahasiswa terhadap Gagasan Legalisasi Ganja di Indonesia”, Jurnal Hukum Samudera Keadilan, Volume 13 Nomor 2, hal 235

7) Tim Lgn, Op. Cit., hal. 5 
Volume 2 Nomor 2, Desember 2019

E-ISSN : 2655-7347

pada tanggal 20 Desember $2013,{ }^{8)}$ dan Uruguay menjadi negara pertama yang melegalkan Ganja.

Menteri Kesehatan Irlandia Simon Harris telah menandatangani program percobaan lima tahun akses ganja medis. Harris mengungkapkan bahwa program tersebut ditujukan untuk memfasilitasi ganja hanya dalam keperluan medis dimana pengobatan konvensional telah dianggap gagal.Program tersebut memungkinkan akses ganja medis hanya untuk tiga kondisi seperti mual dan muntah yang tidak dapat diatasi terkait dengan pengobatan kemoterapi, epilepsi parah yang resisten terhadap pengobatan, dan pengobatan yang berkaitan dengan multiple sclerosis.Program percobaan akes ganja medis tidak berarti pula disahkannya produksi ganja medis di Irlandia. Harris juga menambahkan bahwa pasien dari program ganja medis ini akan dilindungi oleh asuransi. Program ini menjadi langkah awal bagi Irlandia untuk membuka akses terhadap penggunaan ganja untuk kepentingan medis. Harris menegaskan bahwa program ini bukan merupakan suatu batu loncatan untuk legalisasi ganja yang bersifat rekreatif dan yang terpenting adalah tidak ada rencana legalisasi ganja di Irlandia.Program percobaan lima tahun akses ganja medis ini akan berjalan di bawah pengawasan Menteri Kesehatan Simon Harris dan akan ditinjau kembali pada tahun 2024.9)

Negara selanjutnya adalah Thailand dimana disahkan oleh parlemen yang dibentuk oleh rezim militer Thailand. Pada pembahasannya, Parlemen Thailand memberikan dukungan atas diubahnya UU Narkotika tahun 1979.Pemeintah Thailand resmi melegalkan ganja sebagai keperluan medis pada 1 Januari 2019.Ganja sebagai kepentingan medis ini kemudian akan diatur ketat oleh pemerintah Thailand melalui lisensi produksi dan penjualan.

\footnotetext{
8) Pebrianto Nainggolan, "Kepentingan Pemerintah Uruguay Melegalisasi Ganja Pada Masa Pemerintahan Jose Alberto Mujica Cordano Tahun 2010-2015”, Jurnal Fisip UR, Vol 2 Nomor 2

${ }^{9\}}$ Anonim, “ Irlandia Mengesahkan Akses Ganja Medis Berjangka” . www.lgn.or.id. Diakses
} 10 Juni 2019 
Volume 2 Nomor 2, Desember 2019

E-ISSN : 2655-7347

Kepemilikan ganja secara perorangan dalam jumlah tertentu diatur denganmemiliki resep dan sertifikasi yang diakui oleh pemerintah.Pemerintah Thailand menegaskan bahwa undang-undang tersebut juga berlaku untuk Kratom yang merupakan tanaman stimulan. ${ }^{10\}}$

Berdasarkan perjalanan kontroversial ganja yang menjadi ilegal dan diatur keras dalam hukum Indonesia saat ini, padahal sangat lekat dengan budaya sebagian daerah Indonesia beserta kegunaan lainnya yang memberi manfaat, lahirlah suatu kejadian kotroversial yang sangat menarik untuk diteliti. Hal ini dilihat dari adanya suatu kelompok yang mendukung untuk dilegalkannya ganja. Gagasan ini menjadi suatu gerakan yang disasarkan kepada masyarakat untuk setuju dan percaya bahwa ganja seharusnya menjadi tanaman yang legal, khususnya di Indonesia. Salah satu penggagas legalisasi ganja di Indonesia adalah Lembaga Swadaya Masyarakat (selanjutnya disebut LSM) yang bernama Lingkar Ganja Nusantara. Organisasi ini berawal grup facebook yang bernama "Dukung Legalisasi Ganja". Dengan tujuan untuk membuat ganja menjadi legal di Indonesia, para pengurusnya aktif menyosialisasikan manfaat tanaman ganja kepada semua elemen individu yang ada di Indonesia. Atas dasar ini, "Lingkar Ganja Nusantara" memiliki aktivitas sebagai LSM yang bertugas menyebarkan informasi dan memberikan edukasi mengenai tanaman ganja, hubungan serta manfaatnya bagi manusia kepada seluas-luasnya masyarakat. ${ }^{11)}$

Di dalam beberapa contoh kasus yang memakai ganja untuk kesehatan, salah satu contohnya adalah kasus pada Putusan Nomor 111/Pid.Sus/2017/Pn.Sag yaitu Fidelis Arie Sudewarto yang terjadi pada 19 Februari 2017, di mana Fidelis diketahui menanam tanamanganja di rumahnya, dan mengelolah ganja tersebut menjadi ekstrakganja laludipakai

${ }^{10)}$ Anonim, “Thailand Resmi Legalkan Ganja untuk Kesehatan. www.lgn.or.id. Diakses 10 Juni 2019

11) Hanri Aldino, Op. Cit., hal. 236 - 237 
Volume 2 Nomor 2, Desember 2019

E-ISSN : 2655-7347

untuk mengobati istrinya yang terkena penyakit langkah. Sebelum ia melakukan pengobatan menggunakan ekstrak ganja, ia sudah mencoba berbagai pengobatan dari pengobatan tradisional dan pengobatan medis namun dokter yang menanganinya tidak dapat menyebuhkan. Fidelis sendiri meminta dispensasi kepada Badan Narkotika Nasional (BNN) atas pemakaian ganja yang ia pakai untuk istrinya tapi yang terjadi setelah ia meminta dispensasi, ia malah ditangkap.

Contoh kasus kedua, pada tanggal 27 februari 2019, Sutikno dan Iqbal Munafi di Banyumas yang tertangkap karena ketahuan menanam ganja di pot kecil di halaman rumahnya, ganja tersebut ia pakai untuk mengobati Ibunya yang sedang sakit diabetes. Salah satu alasan ia memakai ganjadikarenakan kekurangan biaya yang ia miliki sehingga ia menggunakan Ganja. ${ }^{12)}$

Menurut penulis, hal ini menarik untuk diangkat sebagai skripsi karena terjadi kesenjangan sosial yang cukup kelihatan antara Undang - Undang Narkotika di Indonesia mengenai pelarangan penggunaan Ganja dengan manfaat Ganja yang berguna untuk kesehatan.

Setelah menguraikan latar belakang yang ada di atas, penulis memutuskan untuk mengkaji mengenai hal ini dalam bentuk proposal penulisan skripsi dengan judul Kebijakan Hukum Pidana Penggunaan Narkotika Golongan 1 (satu) jenis “Ganja” untuk Kesehatan.

\section{B. Perumusan Masalah}

Setelah latar belakang masalah yang telah diuraikan tadi, makadapat dirumuskan pokok masalah yaitu:

1. Apakah putusan hakim dapat diperingan mengenai denda yang dijatuhkan?

2. Bagaimana penerapan asas keadilan dalam pengambilan putusan hakim?

\section{Maret 2019}

12) Anonim, "Pria Asal Banyumas Tanam Ganja untuk Obati Ibunya". www.tribunnews.com. 3 
Volume 2 Nomor 2, Desember 2019

E-ISSN : 2655-7347

\section{Metode Penelitian}

Metode penelitian dalam suatu karya ilmiah sangat diperlukan untuk menentukan metode apa yang akan digunakan agar tujuan dari penelitian terarah pada tujuan yang hendak dicapai. Adapun metode yang digunakan sebagai berikut:

1. Jenis Penelitian

Jenis penelitian yang penulis gunakan adalah penelitian hukum normatif. Penelitian hukum normatif adalah penelitian hukum yang meletakkan hukum sebagai sebuah bangunan norma. Sistem norma yang dimaksud adalah mengenai asas-asas, norma, kaidah dari peraturan perundangan, putusan pengadilan, perjanjian serta doktrin (ajaran). ${ }^{13)}$

\section{Sifat Penelitian}

Dalam penelitian ini, penulis memakai sifat penelitian bersifat deskriptif analitis. Sifat penelitian deskriptif analitis yaitu melakukan deskripsi terhadap hasil penelitian dengan data yang selengkap dan sedetail mungkin.

\section{Jenis Data}

Bahan dasar penelitian hukum normatif adalah bahan pustaka di bidang hukum dari sudut kekuatan mengikatnya dapat dibedakan menjadi tiga golongan, yaitu bahan hukum primer, sekunder dan tersier. ${ }^{14)}$ Di antara lain yang akan digunakan oleh penulis sebagai berikut:

\section{a. Bahan Hukum Primer}

Bahan hukum primer berasalah dari bahan-bahan hukum yang mengikat, seperti norma atau kaidah dasar, peraturan dasar, peraturan perundang-undangan, bahan hukum yang tidak dikodifikasikan, yurisprudensi, traktat dan bahan hukum dari zaman penjajahan yang hingga

13) Mukti Fajar ND dan Yulianto Achmad, Dualisme Penelitian Hukum Normatif dan Empiris, Cetakan ke I, (Yogyakarta: Pustaka Belajar, 2010), hal. 34.

14) Soerjono Soekanto dan Sri Mamudji, Penelitian Hukum Normatif Suatu Tinjauan Singkat, (Jakarta: Raja Grafindo Persada, 2006), hal.33 
Volume 2 Nomor 2, Desember 2019

E-ISSN : 2655-7347

kini masih berlaku. ${ }^{15)}$ Dalam penelitian ini, akan digunakan bahan hukum primer berupaperaturan perundang-undangan antara lain:

1) Peraturan Menteri Kesehatan Republik Indonsia Nomor 50 Tahun 2018 tentang Perubahan Penggolongan Narkotika

2) Undang-Undang Nomor 35 Tahun 2009 tentang Narkotika

b. Bahan Hukum Sekunder

Bahan hukum sekunder yaitu bahan hukum yang dapat memberikan penjelasan terhadap bahan hukum primer, seperti rancangan undang-undang, hasil-hasil penelitian, hasil karya dari kalangan hukum, dan seterusnya. ${ }^{16)}$

Selain data sekunder berupa bahan hukum primer dan sekunder, juga akan digunakan bahan non hukum berupa Kamus Besar Bahasa Indonesia dan Internet.

Kemudian sebagai data penunjang dalam penulisan ini, penulis akan melakukan wawancara dengan beberapa pihak yang akan menunjang penulisan kali ini.

4. Teknik Pengumpulan Data

Teknik pengumpulan data dalam penelitian ini adalah studi kepustakaan terhadap bahan-bahan hukum, baik bahan hukum primer maupun bahan hukum sekunder. ${ }^{17)}$

\section{Teknik Analisis Data}

Analisis data merupakan kegiatan dalam penelitian yang berupa melakukan kajian atau telaah terhadap hasil pengolahan data yang dibantu dengan teori-teori yang telah didapatkan sebelumnya. ${ }^{18)}$ Teknik analisis data yang digunakan dalam penelitian ini adalahpendekatan kwalitatif yaitu penelitian tentang riset yang bersifat deskriptifyang cenderung menggunakan analisis.

\footnotetext{
${ }^{15)}$ Ibid,. hal. 13

16) Ibid,.

17) Mukti Fajar dan Yulianto Achmad, Op.Cit,. hal 160

${ }^{18)}$ Mukti Fajar dan Yulianto Achmad, Op.Cit,. hal. 182
} 
Volume 2 Nomor 2, Desember 2019

E-ISSN : 2655-7347

\section{PEMBAHASAN}

\section{A. Analisis Penetapan Pengadilan Nomor 111/Pid.Sus/2017/Pn.Sag}

Fidelis Arie Sudewarto adalah warga negara Indonesia yang bekerja sebagai Pegawai Negeri Sipil di Kantor Kesatuan Bangsa, Politik, dan Perlindungan Masyarakat Sanggau, Kalimantan Barat. Fidelis diduga melakukan tindak pidana Narkotika sebagaimana diatur dan diancam pidana berdasarkan Undang - Undang Nomor 35 Tahun 2009 Tentang Narkotika.

Padatahun 2013 sekitar awal tahun, Yeni Riawati yang merupakan istri Fidelis Arie Sudewarto (selanjutnya disebut Fidelis) yang terkena penyakit Syringomyelia. Menurut wawnacara yang penulis lakukan, syringomyelia adalah kista yang terdapat di tulang sum - sum belakang. Sakit ini diderita Yeni saat mengandung anak kedua Fidelis dan Yeni. Yeni kemudian dimasukkan ke Rumah Sakit Umum Kabupaten Sanggau untuk dirawat selama kurang lebih 1 (satu) minggu hingga Yeni sehat kembali. Akan tetapi, pada bulan Oktober 2014, penyakitnya kambuh kembali yang akhirnya membuat Yeni mengalami lumpuh di kedua kakinya. Kemudian Yeni dibawa ke Rumah Sakit Antonius Pontianak dan dirawat di sana selama 14 (empat belas) hari lamanya. Karena tidak membuahka hasil, Fidelis lalu mencoba berbagai pengobatan salah satunya ialah pengobatan alternatif di daerah Dusun Bodok, Kecamatan Parindu, Kabupaten Sanggau. Setelah menjalani pengobatan selama kurang lebih 1 (satu) bulan lamanya, pengobatannya membuahkan hasil yang membuat Yeni dapat beraktivitas seperti semula.

Bulan November tahun 2015, Yeni kembali jatuh sakit yang mengakibatkan kedua kakinya lumpuh dan dirawat di Rumah Sakit Sanggau, karena tidak mengalami kemajuan, Yeni lalu dirujuk ke Rumah Sakit Santa Vincensius, Singkawang, dan dirawat selama kurang lebih 1 (satu) minggu. Karena tidak membuahkan hasil, Fidelis memutuskan untuk membawa Yeni 
Volume 2 Nomor 2, Desember 2019

E-ISSN : 2655-7347

pulang ke Sanggau untuk kembali dirawat di Rumah Sakit Umum Sanggau. Saat Yeni sedang dirawat, Yeni dirujuk kembali namun ke Rumah Sakit Umum Darurat Soedarso dan dirawat inap selama kurang lebib 2 (dua) minggu, namun tetap tidak membuahkan hasil. Fidelis lalu memutuskan memulangkan Yeni dan merawat Yeni di rumah. Pada keadaan ini, tubuh Yeni sudah ada kelumpuhan pada kedua kaki, badan, dan tangan sebelah kirinya. Yeni juga mempunyai luka di beberapa bagian tubuhnya. Dengan kondisi Yeni yang tidak membuahkan hasil atau tetap sama, Fidelis kemudian mencari pengobatan lain selain pengobatan medis sembali mencari tentang pengobatan lain untuk Yeni dengan salah satu cara yaitu baca buku dan mengakses info terbaru lewat internet. Dari beberapa buku yang dibaca, Fidelis mengetahui bahwa ganja memiliki khasiat yang dapat digunakan untuk membantu pengobatan.

Selain dari buku yang dibaca, Fidelis pertama kali mendapatkan informasi mengenai penyakit syringomyelia dari internet dan kenal dengan seseorang yang bernama Bet Muryen yang bekewarganegaraan Amerika, kebetulan dia sendiri menderita penyakit yang sama dengan Yeni. Bet Muryen mengatakan kepada Fidelis bahwa penyakit syringomyelia belum ada obatnya yang mana sekalipun dioperasi, hanya untuk memperingan bukan untuk menyembuhkan dan operasi tersebut sangat beresiko. Kemudian Fidelis menemukan tulisan Asna Evan yang ditulis di internet, Asna Evan berasal dari Kanada yang juga mengidap penyakit syringomyelia dan sudah 3 (tiga) tahun menggunakan pengobatan secara medis akan tetapi tidak membuahkan hasil yang kemudian ia menggunakan ganja sebagai pengobatan dan dia bisa bertahan sampai sekarang dan merasakan lebih baik. Kemudian Fidelis mencari tahu lagi dan menemukan artikel salah satu penelitian dari seorang Dokter yang berasal dari Israel yang dia sendiri juga merupakan orang pertama yang berhasil mengisolasikan salah satu kandungan dari ganja dan ia mengatakan bahwa kandungan yang ada pada 
Volume 2 Nomor 2, Desember 2019

E-ISSN : 2655-7347

ganja mampu untuk mengobati beberapa penyakit seperti kanker, epilepsi, dan lain - lain. Selain ini, Fidelis mencari lagi penelitian yang lain tentang ganja dan mendapatkan banyak hasil penelitian tentang ganja.

Dalam penelitian ini, penulis memilih untuk meneliti mengenai penjatuhan pidana yang dijatuhkan kepada Fidelis. Analisis penulis sebagai berikut:

Hakim sebagai aparatur penegak hukum. Hakim juga sebagai pelaksana hukum yang mengupayakan untuk menuntaskan kasus yang diberikan kepadanya karena hakim mempunyai hak penuh di dalam memutuskan suatu perkara atau kasus. Hakim merupakan unsur utama di dalam persidangan yang ada di pengadilan, bahkan identik dengan pengadilan tersebut. Kebebasan kekuasaan kehakiman sering kali diidentikkan dengan kebebasan hakim. Oleh karena itu, pencapaian penegakan hukum dan keadilan terletak pada kemampuann dan kearifan hakim dalam merumuskan keputusan yang mencerminkan keadilan. Mengigat hakim merupakan orang yang mengadili suatu kasus atau perkara (di Pengadilan ataupun Mahkamah Konstitusi). Pasal 11 Undang - Undang Nomor 7 Tahun 1989 tentang Peradilan Agama menyatakan bahwa "hakim adalah pejabat yang melaksanakan tugas kekuasaan kehakiman”.

Kewenangan yang diberikan kepada hakim untuk mengambil suatu kebijaksanaan dalam memutus perkara, diatur dalam Pasal 5 Ayat (1) Undang - Undang Nomor 48 Tahun 2009 tentang Kekuasaan Kehakiman, yang menetukan: "hakim dan hakim konstitusi wajib menggali, mengikuti, dan memahami nilai - nilai hukum dan rasa keadilan yang hidup dalam masyarakat".

Hakim dalam memutuskan suatu kasus atau perkara pasti akan selalu diperhadpakan dengan yang namanya keadilan, artinya hakim selalu dituntut berlaku adil dalam memutuskan suatu kasus atau perkara yang diberikan kepadanya. Persoalan yang dihadapi hakim untuk terpenuhinya suatu unsur 
Volume 2 Nomor 2, Desember 2019

E-ISSN : 2655-7347

keadilan adalah menghadapi suatu perkara atau kasus yang dilatarbelakangi oleh perbedaan latar belakang, motivasi terjadinya suatu kasus dan lain - lain sekalipun persoalan hukum dari beberapa kasus yang sama.

Putusan hakim harus dilandasi oleh pertimbangan yang jelas dan cukup. Menurut Undang - Undang Nomor 48 Tahun 2009 tentang Kekuasaan Kehakiman Pasal 53 menyatakan:

1. Dalam memeriksa dan memutus perkara, hakim bertanggung jawab atas penetapan dan putusan yang dibuatnya;

2. Penetapan dan putusan sebagaimana dimaksud pada ayat (1) harus membuat pertimbangan hukum hakim yang didasarkan pada alasan dan dasar hukum yang tepat dan benar.

Tindak Pidana Narkotika merupakan kejahatan luar biasa (extra ordinary crime) yang diatur secara khusus dalam Undang - Undnag Nomor 35 Tahun 2009 tentang Narkotika. Pembuatan Undang - Undang ini dilakukan untuk menjamin ketersediaan narkotika guna kepentingan pelayanan kesehatan dan ilmu pengetahuan, serta mencegah terjadinya penyalahgunaan narkotika dan memberantas pengedaran gelap narkotika. ${ }^{19)}$

Perbuatan menyimpan, membuat, mengedarkan, dan menggunakan narkotika tanpa pembatasan dan pengawasan yang seksama dan bertentangan dengan peraturan perundang - undangan yang berlak merupakan suatu kejahatan. $^{20)}$

Terkait dengan hal tersebut, kasus ini telah diputus oleh Pengadilan Negeri Sangau Nomor 111/Pid.Sus/2017/Pn.Sag pada tanggal 2 Agustus 2017. Majelis Hakim menyatakan bahwa Fidelis terbukti bersalah melakukan tindak pidana tanpa hak dan melawan hukum karena telah menggunakan Ganja (Narkoba Golongan 1 (satu)) terhadap orang lain sebagaimana sudah

\footnotetext{
${ }^{19)}$ Jandi Mukianto, Prinsip dan Praktik Bantuan Hukum di Indonesia, (Depok: Kencana, 2017) hal. 33

${ }^{20)}$ A.R Sujono dan Bony Daud dan Daniel, Komentar dan Pembahasan Undang - Undang Nomor 35 Tahun 2009 tentang Narkotika, (Jakarta: Sinar Grafika, 2011) hal. 10
} 
Volume 2 Nomor 2, Desember 2019

E-ISSN : 2655-7347

diatur dalam Pasal 116 Undang - Undang Nomor 35 Tentang Narkotika yang menyatakan:

"Setiap orang yang tanpa hak atau melawan hukum menggunakan Narkotika Golongan 1 terhadap orang lain atau memberikan Narkotika Golongan 1 untuk digunakan orang lain, dipidana dengan pidana penjara paling singkat 5 (lima) tahun dan paling lama 15 (lima belas) tahun dan pidana denda paling sedikit Rp1.000.000.000 (satu miliyar rupiah) dan paling banyak Rp10.000.000.000 (sepuluh miliyar rupiah).”

Majelis Hakim menjatuhkan hukuman pidana terhadap Fidelis yaitu pidana penjara selama 8 (delapan) bulan dan denda sebesar Rp. 1.000.000.000 (satu miliyar rupiah) dengan ketentuan jika denda tersebut tidak dibayar maka Fidelis harus ganti dengan pidana penjara selama 1 (satu) bulan lamanya.

Majelis Hakim juga menganggap bahwa Fidelis memenuhi unsur unsur yang ada di dalam Pasal 116 yaitu:

a. Setiap Orang

Undang - Undang Nomor 35 Tahun 2009 tentang Narkotika tidak memberikan definisi yang jelas tentang apa yang dimaksud dengan setiap orang, namun demikian terminologi setiap orang yang dimaksud disini tidak lain merupakan padanan kata dari barangsiapa yang biasa dipergunakan dalam rumusan delik KUHP yang merupakan subyek hukum yaitu orang atau manusia yang memiliki hak dan kewajiban dalam lapangan hukum, subyek hukum mana dapat dimintai pertanggungjawabannya dalam hal subyek hukum tersebut melakukan tindak pidana. Setelah Majelis Hakim memeriksa secara seksama seluruh berkas perkara, dan meyakini bahwa Fidelis merupakan orang dan tidak ada kekeliruan (error inpersona) dan juga selama proses pemeriksaan di persidangan, Fidellis dapat menjawab dengan tegas semua pertanyaan yang diberikan kepadanya oleh Majelis Hakim ataupun 
Volume 2 Nomor 2, Desember 2019

E-ISSN : 2655-7347

penuntut umum. Sehingga itu berdasarkan pertimbangan pertimbangan di atas, Majelis Hakim meyakini unsur setiap orang telah terpenuhi.

b. Melawan Hukum atau Tanpa Hak

Tanpa hak adalah tidak memiliki kewenangan dan melakukan suatu perbuatan, sedangkan yang dimaksud dengan melawan hukum diartikan secara formil sebagai suatu perbuatan yang bertentangan dengan ketentuan peraturan perundang - undangan yang berlaku atau bertentangan dengan hukum positif secara materil yakni suatu perbuatan tidak diatur dalam suatu peraturan perundang - undangan namun karena perbuatan tersebut dirasa bertentangan dengan keputusan maka perbuatan tersebut dilarang.

c. Menggunakan Narkotika Golongan 1 terhadap orang lain atau memberikan Narkotika Golongan 1 untuk digunakan orang lain. Yang dimaksud dengan menggunakan narkotika dapat disimpulkan sebagai memasukkan ke dalam tubuh manusia baik melalui mulut ataupun alat bantu. Majelis menganggap Fidelis memenuhi unsur ini berdasarkan keterangan saksi, keterangan terdakwa, dan barang bukti.

Sebelum menjatuhkan pidana terhadap Fidelis, hakim mempertimbangkan keaadaan yang memberatkan dan keadaan yang meringankan yang ada pada Fidelis, sebagai berikut:

Keadaan yang memberatkan adalah bahwa Fidelis tidak membantu Pemerintah dalam memberantas Narkoba.

Keadaan yang meringankan:

- Fidelis tidak pernah dihukum;

- Fidelis menggunakan Narkoba untuk kesehatan 
Volume 2 Nomor 2, Desember 2019

E-ISSN : 2655-7347

- Fidelis merupakan tulang punggung untuk anak - anaknya setelah istrinya meninggal

Fidelis pun mendapatkan sanksi denda sebesar Rp1.000.000.000 (satu milyar rupiah), menurut penulis seharusnya Fidelis bisa mendapatkan denda dibawah Rp1.000.000.000 (satu milyar rupiah) karena hakim mempunyai kebebasan dalam memutuskan suatu putusan karena menurut penulis denda yang dijatuhkan kepada Fidelis terlalu besar.

Sebagaimana yang telah diuraikan pada bab sebelumnya, bahwasannya Fidelis telah melakukan upaya pengobatan medis ke beberapa rumah sakit, namun karena tidak membuahkan hasil dan tim medis juga telah angkat tangan terkait rangkaian dengan pengobatan Yeni, maka oleh karena itu Fidelis berinisiatif untuk menyembuhkan Yeni dengan ganja agar ada peningkatan kesehatan dalam upaya meringankan rasa sakit yang diderita Yeni.

Di dalam hukum pidana juga dikenal adanya alasan pembenar sebagaimana menuru pendapat E. Utrecht yang dikutip oleh Frans Maramis dalan bukunya yang berjudul Hukum Pidana Umum dan Tertulis di Indonesia adalah sebagai beirkut:

"Rechtvaardigingsgronden (alasan - alasan yang membernarkan) itu menghapuskan wederrechtelijkheid dan schulduitsluitingsgronden (alasan alasan yang menghilangkan kesalahan dalam arti kata luas) hanya menghilangkan pertanggungjawaban (toerekenbaarheid) pembuat atas peristiwa yang diadakannya. Umum diterima pendapat bahwa Rechtvaardigingsgronden menghapuskan suatu peristiwa pidana, yaitu kelakuan yang bersangkutan bukan suatu peristiwa pidana, biarpun sesuai dengan lukisan suatu kelakuan tertentu yang dilarang dalam - undang pidana, sedangkan dalam hal schulduitsluitingsgronden kelakuan yang bersangkutan 
Volume 2 Nomor 2, Desember 2019

E-ISSN : 2655-7347

tetap suatu peritiwa pidana tetapi tidak dapat dipertanggungjawabkan (toegerekend) kepada pembuat."

Moeljanto berpendapat bahwa alasan pembenar merupakan alasan yang dapat menghapuskan sifat melawan hukumnya perbuatan, sehingga apa yang dilakukan oleh terdakwa selanjutnya menjadi perbuatan yang patut dan dibenarkan. ${ }^{21)}$ Selain alasan penghapusan pidana di dalam undang - undang dikenal pula alasan penghapusan pidana di luar undang - undang. Menurut Utrech, seharusnya kita menerima keberadaan dari alasan - alasan penghapusan pidana di luar undang - undang, di mana sumber untuk itu adalah hukum kebiasaan, hukum adat, dan norma - norma lainnya yang tidak tercantum dalam undang - undang. ${ }^{22)}$

Majelis Hakim mengesampingkan pembelaan terdakwa atau Penasihat Hukum Fidelis yang menyatakan bahwa, perbuatan terdakwa yang telah menanam ganja untuk pengobatan isterinya adalah suatu perbuatan yang tergolong sebagai Overmacht sebagaimana diatur dalam Pasal 48 KUHP.

Bahwa dalam ketentuan KUHP disebutkan alasan pembenar diatur dalam Pasal 48 (keadaan darurat), Pasal 49 ayat (1) (pembelaan terpaksa). Dalam keadaan tertentu, Fidelis tidak dapat berbuat yang lain yang berujung pada terjadinya tindak pidana, sekalipun sebenarnya hal ini tidak diinginkan oleh Fidelis. Terjadinya tindak pidana tidak dapat dihindari oleh terdakwa karena sesuatu yang berasal dari luar dirinya. Faktor inilah yang menyebabkan terdakwa tidak dapat berbuat lain yang mengakibatkan kesalahannya menjadi terhapus. $^{23)}$

Menurut penulis, Pasal yang ditetapkan kepada Fidelis oleh Pengadilan Negari Sangau dirasa kurang efektif, terlebih lagi saat Fidelis sedang

\footnotetext{
${ }^{21)}$ Frans Maramis, Hukum Pidana Umum dan Tertulis di Indonesia, (Jakarta: PT Raja Grafindo Persada, 2012), hal. 135

${ }^{22)}$ Ibid, hal. 139

${ }^{23)}$ Mahrus Ali, Dasar-Dasar Hukum Pidana, (Jakarta: Sinar Grafindo, 2011), hal. 180
} 
Volume 2 Nomor 2, Desember 2019

E-ISSN : 2655-7347

menjalani masa tahanan, kondisi Yeni semakin menurun dan menyebabkan Yeni meninggal dunia.

Menyadari kenyataan demikian, seharusnya pemerintah bisa memberikan suatu perlindungan terhadap rakyatnya, perlindungan yang dimaksud seperti penghapusan pidana karena keadaan darurat atau daya paksa.

Seperti yang dinyatakan dalam Pasal 48 KUHP, yaitu:

"Barang siapa melakukan perbuatan karena pengaruh daya paksa, tidak dipidana”.

Karena menurut penulis, apa yang dilakukan Fidelis merupakan suatu keterpaksaan atau daya paksa, karena Fidelis terpaksa memberikan ganja kepada Yeni mengingat sudah berbagai cara yang dilakukan namun tidak membuahkan hasil.

Menurut penulis, jika posisi Fidelis dibalikkan ke posisi orang lain, mungkin orang lain tersebut juga melakukan hal yang sama karena semua orang pasti akan berusaha untuk memperjuangkan orang yang kita kasihi untuk tetap bisa bertahan hidup.

Keadaan darurat merupakan salah satu bentuk daya paksa (overmacht) yang pada umumnya terdapat dalam salah satu bentuk kejadian seperti berikut: ${ }^{24)}$

1. Adanya pertentangan antara dua kepentingan hukum

2. Adanya pertentangan antara kepentingan dan kewajiban hukum

3. Adanya pertentangan antara dua kewajiban

Berdasarkan peristiwa yang dialami oleh Fidelis, penulis dapat menyatakan bahwa terdapat pertentangan antara kepentingan dan kewajiban hukum. Di satu sisi Fidelis mempunyai kepentingan untuk mengobati istrinya yang sedang sakit kista sum - sum tulang belakang, namun di sisi lain Fidelis

${ }^{24)}$ Guse Prayudi, Seluk Beluk Hukum Pidana yang Penting untuk Diketahui, (Jakarta: Boya Book, 2008), hal. 92 
Volume 2 Nomor 2, Desember 2019

E-ISSN : 2655-7347

sebagai warga negara Indonesia dituntut untuk mentaati segala peraturan perundang - undangan yang berlaku, dalam hal ini adalah Undang - Undang Nomor 35 Tahun 2009 tentang Narkotika.

Menurut Mr. Tirtaadimadjaa, syarat - syarat agar keadaan darurat dapat diterima apabila: ${ }^{25)}$

1. Harus ada suatu pertimbangan antara kepentingan yang dipertahankan dan kepentingan yang dikorbankan oleh perbuatan itu;

2. Orang yang bertindak dalam keadaan yang memaksa itu tidak boleh mempunyai jalan lain untuk menyelamatkan diri;

3. Orang yang bertindak dalam keadaan memaksa itu, tidak boleh seorang yang karena pekerjaannya atau kewajibannya harus menentang segala bahaya untuk melakukan pekerjaan atau kewajibannya itu, bahkan dengan mengorbankan nyawanya.

Disini penulis meneliti bahwa Fidelis memenuhi syarat - syarat yang tercantum di atas. Kepentingan yang dipertahankan Fidelis dalam hal ini adalah mengobati Yeni yang sedang sakit kista sum - sum tulang belakang dengan menggunakan Narkotika Golongan 1 jenis ganja agar Yeni bisa bertahan hidup lebih lama. Narkotika Golongan 1 adalah narkotika yang dilarang untuk digunakan dalam kepentingan pelayanan kesehatan. Sehingga perbuatan terdakwa tersebut dianggap melanggar Undang - Undang Nomor 35 Tahun 2009 tentang Narkotika.

Mengigat Yeni yang menderita penyakit Syringomyelia sejak lama dan Fidelis sudah mencoba berbagai cara pengobagtan untuk mengobati Yeni dan tidak membuahkan hasil, maka oleh itu menurut pengamatan penulis sudah tidak ada jalan lain yang bisa dilakukan oleh Fidelis untuk membantu Yeni

\footnotetext{
${ }^{25)}$ Laden Marpaung, Asas Teori Praktik Hukum Pidana, (Jakarta: Sinar Grafika, 2008), hal. 57
} 
Volume 2 Nomor 2, Desember 2019

E-ISSN : 2655-7347

agar tetap bisa bertahan hidup oleh karena itu Fidelis memberikan ganja kepada Yeni.

Berdasarkan uraian tersebut, menurut penulis syarat - syarat mengenai keadaan darurat telah terpenuhi. Fidelis melakukan tindak pidana tersebut karena keadaan darurat yang dialaminya.

Terlebih lagi, Fidelis melakukan perbuatan tersebut tidak didasari atas niat jahat untuk mencelakai orang lain.

Sesungguhnya untuk meniliat suatu putusan yang mengandung keadilan, sulit dicarikan tolak ukurnya bagi pihak - pihak yang berperkara di pengadilan karena adil bagi satu pihak belum tentu adil untuk pihak yang lain yang berperkara.

Keadilan menurut Aristoles dibagi ke dalam dua macam keadilan, keadilan “distributief”'dan keadilan "commutatief”. Keadilan distributief ialah keadilan yang memberikan kepada tiap orang menurut pretasinya. Keadilan commutatief memberikan sama banyaknya kepada setiap orang tanpa membeda - bedakan prestasina dalam hal ini berkaitan dengan peranan tukar menukar barang dan jasa. ${ }^{26)}$

Beberapa konsep keadilan yang dikemukakan oleh Filsuf Amerika di akhir abad ke- 20, John Rawles, seperti A Theory of Justice, Political Liberalism, dan the Law of Peoples, yang memberikan pengaruh pemikiran cukup besar terhadap diskursus nilai - nilai keadilan. ${ }^{27)}$

John Rawls yang dipandang sebagai prespektif "liberal-egalitarian of social justice", berpendapat bahwa keadilan adalah kebijakan utama dari hadirnya institusi - intitusi sosial (social institutions). Akan tetapi kebijakan bagi seluruh masyarakat tidak dapat mengesampingkan atau menggugat rasa

\footnotetext{
${ }^{26)}$ Carls Joachim Friedrich, Op, Cit, hal. 25

${ }^{27)}$ Pan Mohamad Faiz, Op, Cit, hal. 35
} 
Volume 2 Nomor 2, Desember 2019

E-ISSN : 2655-7347

keadilan dari setiap orang yang telah memperoleh rasa keadilan khususnya masyarakat lemah pencari keadialan. ${ }^{28)}$

John Rawls juga mengungkapkan suatu gagasan mengenai prinsip prinsip keadilan dengan menggunakan sepenuhnya konsep ciptaannya yang dikenal dengan "posisi asli" (original position) dan "selubung ketidaktahanan" (veil of ignorance) ${ }^{29)}$

Hans Kalsen juga mengungkapkan tentang konsep keadilan yang mencakup dua hal, yaitu: pertama tentang keadilan dan perdamaian. Keadilan yang bersumber dari cita - cita irasional. Keadilan dirasionalkan melalui pengetahuan yang dapat berwujud suatu kepentingan - kepentingan yang pada akhirnya menimbulkan suatu konflik kepentingan. Penyelesaian atas konflik kepentingan tersebut dapat dicapai melalui suatu tatanan yang memuaskan salah satu kepentingan dengan mengorbankan kepentingan yang lain atau dengan berusaha mencapai suatu kompromi menuju suatu perdamaian bagi semua kepentingan. ${ }^{30)}$

Kedua, konsep keadilan dan legalitas. Untuk menegakkan diatas dasar suatu yang kokoh dari suatu tanaman sosial tertentu, menurut Hans Kelsen pengertian "Keadilan" bermaknakan legalitas. Suatu peratutan umum adalah "adil" jika ia benar - benar diterapkan pada suatu kasus dan tidak diterapkan pada kasus lain yang serupa. ${ }^{31)}$ Konsep keadilan dan legalitas inilah yang diterapkan dalam hukum nasional bangsa Indonesia, yang memaknai bahwa peraturan hukum nasional dapat dijadikan sebagai sebagai payung hukum (law umbrella) bagi peraturan - peraturan hukum nasional lainnya sesuatu tingkat dan derajatnya dan peraturan hukum itu memiliki daya ikat terhadap

\footnotetext{
${ }^{28)}$ Ibid, hal. 140

29) Ibid, hal. 140

30) Kahar Masyur, “Membina Moral dan Akhlak”, (Jakarta: Kalam Mulia, 1985), hal. 68

${ }^{31)}$ Ibid, hal. 71
} 
Volume 2 Nomor 2, Desember 2019

E-ISSN : 2655-7347

materi - materi yang dimuat (materi muatan) dalam peraturan hukum tersebut. $^{32)}$

Jika dilihat tingkatannya, KUHP tingkatannya lebih tinggi dari pada Undang - Undang Nomor 35 Tahun 2009 Tentang Narkotika. Oleh sebab itu, menurut penulis, seharusnya pembelaan Fidelis dan kuasa hukumnya bisa dikabulkan oleh Majelis Hakim.

Menurut penulis, unsur keadilan tidak terpenuhi karena tidak terkabulnya pembelaan Fidelis yang seharusnya Fidelis bisa bebas dari hukuman penjara dan denda karena melakukan suatu tindak pidana karena keterpaksaan.

Hukum mempunyai kedudukan yang berguna bagi masyarakat. Sebagai bagian dari cita hukum, keadilan dan kepastian hukum membutuhkan pelengkap di dalam memutuskan suatu perkara yaitu kemanfaatan hukum. Baik buruknya suatu hukum bergantung pada apakah hukum itu memberikan kebahagiaan atau tidak pada manusia. Masyarakat selalu berharap manfaat dalam melaksanaan dan menegakan hukum. Hukum adalah untuk manusia maka pelaksanaan hukum atau penegakkan hukum harus memberi manfaat atau kegunaan bagi masyarakat. Pelaksanaan dan penegakkan hukum harus dapat menghindarkan timbulnya persilangan pendapat di dalam masyarakat. Hukum yang baik adalah peraturan yang membawa kemanfaatan bagi manusia. Kemanfaatn di sini jugae dapat diartikan dengan kebahagiaan. Masyarakat akan menaati hukum tanpa perlu dipaksa dengane sanksii apabilas memang masyarakat merasakan manfaatr. ${ }^{33)}$

Menurut penulis, setelah kasus Fidelis terdapat pro kontra di antara masyarakat mengenai ganja dan apa yang tertimpa terhadap Fidelis, dari Yeni yang meninggal dunia dan Fidelis yang mendapat hukuman penjara dan denda.

\footnotetext{
${ }^{32)}$ Ibid, hal. 71

${ }^{33)}$ Fence M. Wantu, Op, Cit.
} 
Volume 2 Nomor 2, Desember 2019

E-ISSN : 2655-7347

Beberapa orang yang pernah penulis tanyakan pun, sebagian menganggap bahwa hukum kadang tidak berpihak kepada rakyat yang lemah.

Dengan mempertimbangkan fakta - fakta yang telah diuraikan di atas, penulis berpendapat bahwa perbuatan Fidelis merupakan suatu tindak pidana yang dilakukan dalam keadaan terpaksa dan seharsnya dapat dipertimbangkan oleh Majelis Hakim untuk menjadi dasar pembenar dan menghapuskan sifat melawan hukum dalam perbuatan Fidelis.

\section{PENUTUP}

\section{A. Kesimpulan}

Setelah analisis yang telah tercantum di atas, oleh karena itu penulis dapat memberikan kesimpulan bahwa perbuatan yang dilakukan oleh Fidelis adalah perbuatan tindak pidana yang didasarkan oleh keadaan darurat dan daya paksa atau terpaksa. Pendapat penulis didasarkan oleh pembelaan Fidelis, pernyataan para saksi, dan meninggalnya Yeni saat Fidelis sedang dalam tahanan.

Dampak dari putusan Majelis Hakim ialah berkurangnya rasa kepercayaan masyarakat akan Pengadilan sebagai tempat pencari keadilan. Dalam kasus ini dibutuhkan pertimbangan hukum yang didasari oleh keadilan hukum, kemanfaatan hukum, dan hati nurani sebagai manusia.

Mengenai ganja, penulis menarik kesimpulan bahwa ganja bisa menjadi obat atau pengobatan untuk orang yang terkena penyakit, hal ini didasarkan berdasarkan hasil wawancara penulis dengan Ketua Asosiasi Rehabilitasi dan juga dengan pelegalan ganja untuk pengobatan di beberapa negara.

\section{B. Saran}

Bagi pemerintah, agar mencegah hal serupa seperti ini agar tidak terjadi lagi. Pemerintah diharapkan juga dapat menyusun regulasi yang sesuai dengan ilmu pengetahuan dan perkembangan khususnya dalam bidang medis untuk pengobatan menggunakan ganja. 
Volume 2 Nomor 2, Desember 2019

E-ISSN : 2655-7347

Bagi Majelis Hakim, lebih mempertimbangkan dalam memutuskan suatu putusan agar dapat terpenuhinya unsur keadilan dan kemanfaatan. Jika kasus serupa terjadi lalu Undang - Undang di Indonesia masih melarang penggunanan ganja yang dapat dijadikan pengobatan dalam medis. Majelis Hakim dapat memanggil saksi ahli dalam bidangnya dan membuktikan apakah pernyataan saksi ahli bisa dapat dipercaya atau tidak.

Bagi masyarakat, agar tidak menyalahgunakan penggunaan ganja seperti dilinting lalu dihisap.

\section{DAFTAR PUSTAKA}

\section{A. Buku}

Ali, Mahrus. Dasar - Dasar Hukum Pidana, (Jakarta: Sinar Grafindo, 2011).

Fajar ND, Mukti dan Yulianto Achmad. Dualisme Penelitian Hukum Normatif dan Empiris, Cetakan ke I, (Yogyakarta: Pustaka Belajar, 2010).

Julian, Aristedes. Alegori 420, (Yogyakarta: Vice Versa Books, 2018).

Lgn, Tim.Hikayat Pohon Ganja 12000 Tahun Menyuburkan Peradaban Manusia, Edisi ke -2(Jakarta: Gramedia Pustaka Utama, 2018).

Marpaung, Laden. Asas Teori Praktik Hukum Pidana, (Jakarta: Sinar Grafika, 2008).

Masyur, Kahar. “Membina Moral dan Akhlak”, (Jakarta: Kalam Mulia, 1985).

Maramis, Frans. Hukum Pidana Umum dan Tertulis di Indonesia, (Jakarta: PT Raja Grafindo Persada, 2012).

Mukianto, Jandi. Prinsip dan Praktik Bantuan Hukum di Indonesia, (Depok: Kencana, 2017)

Soekanto, Soerjono dan Sri Mamudji. Penelitian Hukum Normatif Suatu Tinjauan Singkat, (Jakarta: Raja Grafindo Persada, 2006). 
Volume 2 Nomor 2, Desember 2019

E-ISSN : 2655-7347

B. Perundang - undangan

Indonesia. Undang-Undang Nomor 9 Tahun 1976 tentang Narkotika

(Lembaran Negara Repubik Indonesia Tahun 1976 Nomor 37,

Tambahan Lembaran Negara Republik Indonesia Nomor 3086).

. Undang-Undang Nomor 36 Tahun 2009 tentang Kesehatan

(Lembaran Negara Repubik Indonesia Tahun 2009 Nomor 114,

Tambahan Lembaran Negara Republik Indonesia Nomor 5063).

Peraturan Menteri Kesehatan Republik Indonsia Nomor 50 Tahun

2018 tentang Perubahan Penggolongan Narkotika.

\section{Jurnal}

Aldino, Hanri. Persepsi Mahasiswa terhadap Gagasan Legalisasi Ganja di Indonesia, Jurnal Hukum Samudera Keadilan, Volume 13 Nomor 2.

Nainggolan, Pebrianto. Kepentingan Pemerintah Uruguay Melegalisasi Ganja Pada Masa Pemerintahan Jose Alberto Mujica Cordano Tahun 20102015. Jurnal Fisip UR. Vol 2 Nomor 2.

\section{Internet}

Anonim. "Irlandia Mengesahkan Akses Ganja Medis Berjangka” . www.lgn.or.id. Diakses 10 Juni 2019

Anonim. "Thailand Legalkan Ganja untuk Kesehatan” . www.lgn.or.id. Diakses 10 Juni 2019

Anonim. "Pria Asal Banyumas Tanam Ganja untuk Obati Ibunya". www.tribunnews.com . 3 Maret 2019 